\title{
Introducing Health Promotion Agenda-Setting for Health Education Practitioners
}

\author{
Charles T. Kozel ${ }^{1}$, William M. Kane2, Michael T. Hatcher3, Anne P. Hubbell ${ }^{1}$, James W. \\ Dearing ${ }^{4}$, Sue Forster-Cox ${ }^{1}$, Sharon Thompson ${ }^{5}$, Frank G. Pérez ${ }^{5}$, and Melanie Goodman ${ }^{1}$ \\ ${ }^{1}$ New Mexico State University \\ ${ }^{2}$ University of New Mexico \\ ${ }^{3}$ Agency for Toxic Substances and Disease Registry (ATSDR) \\ ${ }^{4}$ Ohio University \\ ${ }^{5}$ University of Texas, El Paso
}

\begin{abstract}
Health professionals must continuously address health promotion issues using the latest strategies and research. Currently in health care, too often an underdeveloped and under supported agenda prioritizes problems, issues, and solutions. Further, an ongoing competition exists among issues due to an undocumented agenda-setting process to gain the attention of media, public, and policy makers. Agendasetting is based on the belief that the media influence what we talk about, rather than controlling what we think, and how often an issue appears in the media influences the policy agenda (Dearing \& Rogers, 1996). If an issue is "salient" and receives frequent or expansive coverage by media, audience members will talk more about that issue than one that is not as salient. A Health Promotion Agenda-Setting approach works to specify and prioritize problems and alternative solutions for increasing media exposure and setting agendas for "sustained" courses of action, (Kozel et al., 2003). The crucial link between agenda-setting and the process of establishing effective legislation, policy, and programs has been researched. However, many health practitioners do not understand what agenda setting is, nor how to apply agenda setting within the field of health education. Professional development in Health Promotion Agenda-Setting offers health education practitioners new knowledge, skills, methods, and opportunities to strengthen practices that influence the public health agenda and transform health promotion leadership.
\end{abstract}

(c) 2006 Californian Journal of Health Promotion. All rights reserved.

Keywords: agenda-setting, health promotion, health education practice

\section{Introduction}

Policy makers take action largely on issues that attain the pinnacle of the policy agenda (Pertschuck, 2001). Exactly how decision makers choose which issues are important continues to be the subject of much research. Is it because they are "popular" or perceived as "hot" topics by members of the media, politically strategic, or genuinely significant health issues? Breckon, Harvey, and Lancaster (1998) stated "a good place to begin...is with a discussion of the concept of politics. In a very real sense, health education (and public health promotion) are intensely concerned with politics as (are) most other important aspects of life" (p. 3). Kingdon (2003) clarified "we want to know something about the game itself. Aside from the participants, we are interested in the processes by which agendas are set and alternatives specified" (p. 16). Agenda-setting addresses both of these and is one way researchers have conceptualized the process of how issues move from relative unimportance to the forefront of policymakers' thoughts (Dearing \& Rogers, 1996).

\section{What is Agenda-Setting?}

An agenda is a set of issues communicated in a hierarchy of importance at any point in time. Agenda-setting addresses the ongoing competition among issues to gain the attention of media professionals, the public and policy elites (Dearing \& Rogers, 1996). What the media relate as important, tell viewers, readers, 
and listeners what issues to talk about (Cohen, 1963). The relative importance of an issue determines how often an issue appears in the media. If an issue is "salient" and receives frequent and/or expansive coverage by media, it is likely audience members will think more about that issue than one that is not as salient. This suggests that the media agenda determines the public agenda (or the problems perceived as most important by the community) which in turn influences what policymakers consider (Dearing \& Rogers, 1996). Private industries such as the pharmaceutical industry have used an agendasetting approach for decades effectively addressing the agenda-setting processes described by Dearing and Rogers for commercial goals (Gosden \& Beder, 2001). The agenda-setting process and the interrelationships among the three agendas is illustrated in Figure 1.

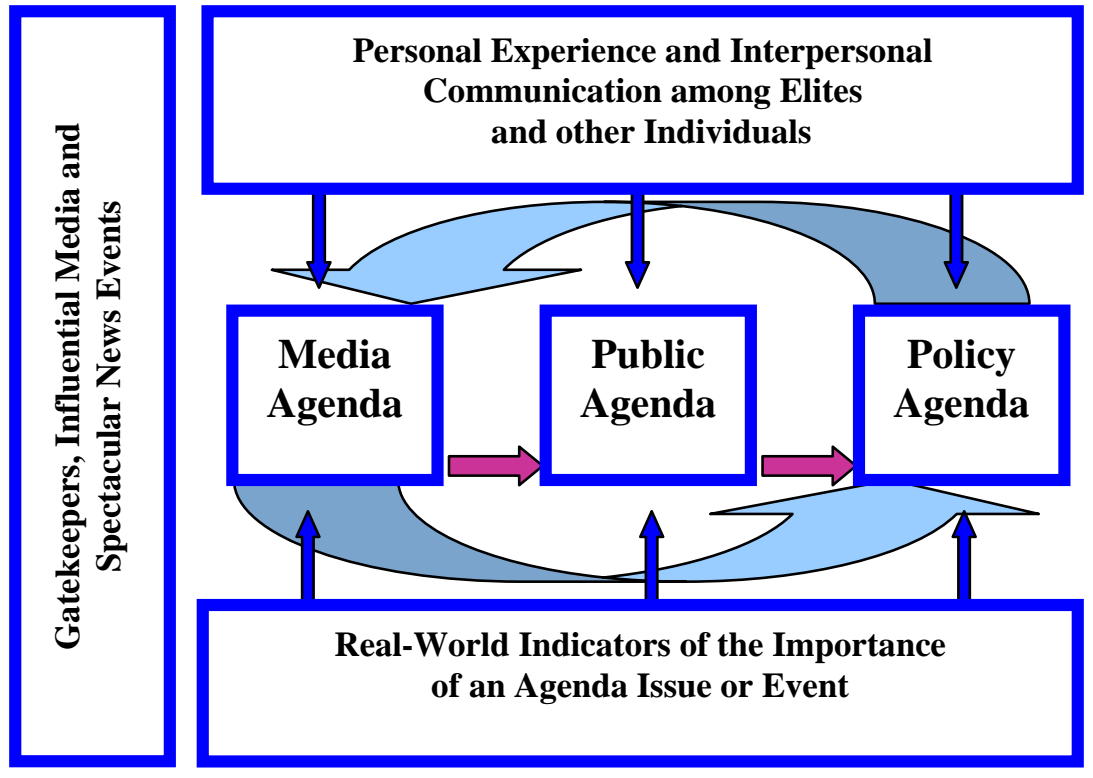

Figure 1

Main Components of the Agenda-Setting Process: Media Agenda, Public Agenda, and Policy Agenda. Adapted (Rogers \& Dearing, 1988; Dearing \& Rogers, 1996).
Dearing and Rogers (1996) identified research related to three types of agenda-setting. The first is media agenda-setting. Its main focus is the priority of an issue on the mass media news agenda (Cohen, 1963; Dearing \& Rogers, 1996; McCombs \& Shaw, 1972). The second, public agenda-setting concentrates on the ordering of one issue in relation to other issues, or the order of a set of issues on the public agenda (Dearing \& Rogers, 1996; Lippmann, 1922; McCombs \& Shaw, 1972). The third, policy agenda-setting, studies how policy actions surrounding an issue function as a response to both media and the public agenda (Cohen, 1963; Cobb \& Elder, 1971; Dearing \& Rogers, 1996; Schattschneider, 1960). Health Promotion Agenda-setting uses interrelationships of the media, public, and policy agendas to explore how health issues move to the forefront of policymakers' actions (Farmer \& Kozel, 2005). This is particularly relevant in the health promotion context. 


\section{Health Promotion Agenda-Setting}

Health Promotion Agenda-Setting (HPA-S) is a process that focuses on how health promotion and public health policy agendas are set and influenced. HPA-S offers an alternative to the scholarly search for direct health promotion and health education effects on individual and group behavior change and overt behavior change (Kozel, Kane, Rogers \& Hammes, 1995). Potentially, the application of agenda-setting to health promotion offers high versatility. The field of health education places a significant focus on intrapersonal, interpersonal, organizational and community-change process theories. However, agenda-setting represents a theoretical basis that offers cross-level analysis (Finnegan \& Viswanath, 2002), cutting across all levels of health education responsibilities. Researching health promotion agenda-setting practices provides health education practitioners and policy makers the potential to improve health promotion and public health performance in the twenty-first century.

HPA-S also is a process of specifying and prioritizing problems and alternative solutions to set agendas for a planned course of action (Kozel et al., 2003; Kozel, Kane, Rogers, \& Hammes, 1995). Key agenda-setting terms applied to the field of health education and public health promotion are summarized in Appendix A.

HPA-S focuses attention on the innovation, diffusion, and adoption of a change process to move an issue to the "critical mass" stage of adoption. Rather than directly intervening to change individual risk behaviors, HPA-S offers health education practitioners guidance for formulating innovative population-focused health policies. HPA-S specifies and prioritizes problems and alternative solutions to set strategic agendas, which may ultimately advance the mission of public health, to protect, promote and preserve the health of the community. (Kozel et al., 2003).

Finnegan and Viswanath (2002) emphasized the possible applications of agenda-setting "by those in public health who seek to use the mass media to raise the salience and awareness of specific health problems” (p. 374). While there is a strong research tradition about agenda-setting, little research exists specific to agenda-setting and health and policy making efforts, even though the agenda-setting approach has contributed to a more advanced understanding of the media's role in society and policy development. Researching agenda-setting practices applied to health promotion provides health education practitioners and policy makers with the potential to improve health promotion leadership.

\section{Health Promotion Agenda-Setting Practices}

There are numerous health promotion and public health planning models that "indirectly" address innovation and diffusion, i.e., the Linkage Approach (Glanz, Lewis, \& Rimer, 2002; Havelock, 1971; Kolbe \& Iverson, 1981; Orlandi, 1990); the Precede/Proceed model (Green \& Krueter, 2005); and the Comprehensive Health Education Model (McKenzie \& Smeltzer, 2005). With these and other models practitioners, working in the health education field, regularly identify, research, and analyze key health issues, develop statements of problems, propose alternative solutions, then educate and/or advocate for improving health promotion policy to create health enhancing change. Agenda-setting theory, however, unifies these previous models. With its cross-cutting basis, it has the potential to be integrated through all seven major responsibility areas of Health Education; including assessing, planning, implementing, coordinating, evaluating, acting a resource person and communicating health education needs (National Commission for Health Education Credentialing, 1999).

HPA-S is a more comprehensive and direct approach to health policy formation. It includes HPA-S characteristic, design and mechanism factors aimed at expanding the diffusion of health promotion, and disease prevention innovations throughout each of the seven major health education responsibility areas. Practicing HPA-S provides a planned course of action for reshaping health promotion leadership and policy (Kozel et al., 2003). The practice of HPA$\mathrm{S}$ also involves creating relevant strategies to maximize the development and diffusion of 
health promotion innovations through media, public and policy agendas. Examples include the use of agenda-setting in the diffusion of designated drivers in DWI prevention efforts
(Dearing \& Rogers, 1996) and the city clean indoor air ordinance (Farmer \& Kozel, 2005). Primary HPA-S interventions and possible agenda-setting applications are listed in Table 1.

Table 1

Agenda-Setting Concepts and Applications. Adapted (Finnegan and Viswanath in Glanz, Rimer \& Lewis 2002 and Kozel et al., 2005)

\begin{tabular}{|l|l|}
\hline \multicolumn{2}{|c|}{ Health Promotion Agenda Setting Innovations } \\
\hline Problem Identification & $\begin{array}{l}\text { Advocate with agenda-setters including community leaders, groups and } \\
\text { organizations to define and prioritize issues. }\end{array}$ \\
\hline $\begin{array}{l}\text { Alternative Solution(s) } \\
\text { Development }\end{array}$ & $\begin{array}{l}\text { Advocate with agenda-setters including community leaders and } \\
\text { organizations to define problems as no longer acceptable and prioritize } \\
\text { acceptable solutions. }\end{array}$ \\
\hline Pre-decision Influence & $\begin{array}{l}\text { Use mechanism factors to influence strategic pre-decision systems and } \\
\text { processes to prevent predetermined agendas. }\end{array}$ \\
\hline Media Agenda Setting & $\begin{array}{l}\text { Work with media professionals to identify and understand their roles, } \\
\text { needs and decision process for selecting and reporting news. }\end{array}$ \\
\hline Public Agenda Setting & $\begin{array}{l}\text { Work with strategic partnerships and media entities to build, foster, and } \\
\text { advocate the public agenda for important health issue solutions. }\end{array}$ \\
\hline Policy Agenda Setting & $\begin{array}{l}\text { Liaison with agenda-setters including community leaders and } \\
\text { policymakers to sustain the importance of health issue solutions on the } \\
\text { media and public agenda. }\end{array}$ \\
\hline Framing & $\begin{array}{l}\text { Position unacceptable problems and acceptable solutions to the media and } \\
\text { public, using factors to foster a shared vision leading to acceptance vs. } \\
\text { exclusion. }\end{array}$ \\
\hline
\end{tabular}

The crucial link between agenda-setting and the process of successfully establishing effective legislation, programs, and policy has been researched. HPA-S offers health practitioners guidance to improve health policy formulation and adoption (Farmer \& Kozel, 2005; Kozel et al., 2003). Through creative research, epidemiology, issue framing, and access to key gatekeepers in the media, public and policy areas, issues that are on the public agenda can be better understood (Backer et al., 1992).

\section{Key Roles for Health Promotion Agenda- Setters}

Health promotion agenda-setters, using agendasetting practices, introduces an innovative advocacy approach to improve health policy formulation and adoption (Kozel et al., 2003).
Health promotion agenda-setters work collaboratively to plan pertinent strategies, methods and systems for a more effective predecision agenda, enhanced health policy formulation and expanded diffusion of health promotion and disease prevention innovations. This is demonstrated by emerging characteristics, and design and mechanism factors. Characteristic factors are descriptive elements or attributes including demographics, which describe the people using the agendasetting process for health promotion. Design factors include strategies and methods used as part of the agenda-setting process for health promotion. Mechanism factors are strategic predecision systems and processes that influence agenda-setting. Strategies, methods and 
processes used by agenda-setters include ten key factors:

1. Networking with individuals, organizations, and communities to ensure mutual success and establish a more efficacious approach to public health and health care reform.

2. Collaborating with stakeholders; corporations through their philanthropic contributions; culture carriers through their influence and endorsement; and health organizations and agencies through their involvement and support (Sullivan, 1991).

3. Forming strategic partnerships locally, nationally, and internationally to create a shared vision for health promotion and disease prevention initiatives.

4. Identifying alternative responses to health and social challenges facing communities when appropriate.

5. Engaging efforts that mobilize, organize, empower, and enable individuals, and grass roots and community based organizations.

6. Sharing ideas and resources (time, money, and exchange) to build synchronicity.

7. Challenging media to refocus their perspectives around media, and public and policy interests to increase the visibility of social and behavioral determinants of health.

8. Sustaining salience, or an elevated priority in the three agenda-setting domains (public, media,and policy agendas) to make a health promotion issue known and important.

9. Tailoring strategies to make a health promotion issue one of the most important shared problems for the community.

10. Influencing and persuading key decision makers and/or gatekeepers to take supportive actions on critical issues.

Health promotion agenda setters are paramount in setting a public health agenda that strives to protect, promote, and preserve the health of our communities. Through collaboration locally, regionally, nationally, internationally, and globally, health promotion agenda-setters strive to set more evidence or theory based health promotion agendas designed to improve health and quality of life.

\section{Conclusion}

Agenda-setting is a method that can be used to address the political process and change the focus from the issue of power to the power of issues (Dearing and Rogers, 1996). If an issue is "salient," it receives frequent or expansive coverage by media. To make an issue more salient, known, or important to a population, health promotion stakeholders must systematically and strategically intervene on the perspectives in all three agenda domains; media, public, and policy. To advance health policy formulation and adoption, the issue must become one of the most important or most unacceptable shared problem in the eyes and hearts of the community to effectively influence the media, public, and policy agendas.

Health Promotion agenda-setters work collaboratively to plan pertinent strategies, methods, and systems for a more effective predecision agenda thereby expanding the diffusion of health promotion and disease prevention innovations. By community groups and leaders forming partnerships, a more collaborative change process will transition health promotion and disease prevention issues to the critical mass stage of adoption.

Presently, numerous groups representing the public and private sectors share strong interests in preparing and using agenda-setting stakeholders to serve in a more effective collaborative diffusion model for priority community, state, national, and international health promotion innovations. Through the eyes of health educators skilled in HPA-S, "shared vision" holds the future for health promotion and health care reform, as well as our collaborative and enduring survival.

\section{References}

Backer, T. E., Rogers, E. M., \& Sopory, P. (1992). Designing health communication campaigns: What works? Newbury Park, CA: Sage.

Breckon, D. J., Harvey, J. R., \& Lancaster, R. B. (1998). Community health education: Settings, roles and skills for the 21st century (4th ed.). Gaitherburg, MD: Aspen Publishers, Inc. 
Cobb, R. W., \& Elder, C. D. (1971). The politics of agenda-building: An alternative perspective for modern democratic theory. Journal of Politics, 33(4), 893-915.

Cohen, B. C. (1963). The press and foreign policy. Princeton, NJ: Princeton University Press.

Dearing, J. W., \& Rogers, E. M. (1996). Agenda-setting. Thousand Oaks, CA: Sage Publications.

Farmer, J., \& Kozel, C. (2005). Agenda-setting and the Albuquerque clean indoor air ordinance. Journal of Health Education, 36(5), 313-315.

Finnegan, J. R., \& Viswanath, K. (2002). Communication theory and health behavior change. In K. Glanz, F. Lewis, \& B. Rimer (Eds.), Health behavior and health education: Theory, research and practice (pp. 361-388). San Francisco, CA: Jossey-Bass. Inc.

Glanz, K., Lewis, F. M., \& Rimer, B. K. (Eds). (2002). Health behavior and health education: Theory, research and practice (3rd ed.). San Francisco: Jossey-Bass, Inc.

Green, L. W., \& Kreuter, M. W. (2005). Health promotion planning: An educational and ecological approach (4th ed.). New York, NY: McGraw-Hill Higher Education.

Gosden, R., \& Beder, S. (2001). Pharmaceutical industry agenda-setting in mental health policies. Ethical Human Sciences and Services, 3(3), 147-159.

Havelock, R. (1971). Planning for innovation through dissemination and utilization of knowledge. Ann Arbor, MI: Institute for Social Research.

Hubbell, A. P., \& Dearing, J. W. (2003). Local newspapers, community partnerships, and health improvement projects: Their roles in a comprehensive community initiative. Journal of Community Health, 28(5), 363-376.

Kingdon, J. W. (2003). Agendas, alternatives, and public policies (2nd ed.). New York, NY: Longman/Addison Wesley Educational Publishers, Inc.

Kolbe, L., Iverson, D., \& Krueter, M. (1981). Proposition for an alternate and explanatory health education paradigm. Health Education, 12, 24-30.

Kozel, C., Kane, W., Rogers, E., \& Hammes, M. (1995). Exploring health promotion agenda-setting design: A study of the factors associated with health promotion agenda-setting design in New Mexico. Unpublished doctoral dissertation, University of New Mexico, Albuquerque.

Kozel, C., Kane, W., Rogers, E., Brandon, J., Hatcher, M., Hammes, M., et al. (2003). Exploring health promotion agenda-setting in New Mexico: Reshaping health promotion leadership. Promotion \& Education, 8(4), 171-177.

Lippmann, W. (1922). Public Opinion. New York: Macmillan

McCombs, M. E. \& Shaw, D. L. (1972). The agenda-setting function of the mass media. Public Opinion Quarterly, 36, 176-187.

McKenzie, J. F. Neiger, B. L. \& Smeltzer, J. L. (2005). Planning, implementing and evaluating health promotion programs ( 4th ed.). San Francisco, CA: Pearson Education, Inc., Benjamin Cummings.

McKinlay, J. B. (1975). A case for refocusing upstream-the political economy of illness. In A. J. Enelow, \& J. B. Henderson (Eds.), Applying behavioral science to cardiovascular risk, conference proceedings, June 17-19, 1974, Seattle, Washington (pp. 7-17). New York: American Health Association.

National Commission for Health Education Credentialing, Inc. (1999). A competency-based framework for graduate level health educators. Allenstown, PA.: Author.

Orlandi, M. A., Landers, C., Weston, R., \& Haley, N. (1990). Diffusion of health promotion innovations. In K. Glanz, F. M. Lewis, \& B. K. Rimer (Eds.), Health behavior and health education: Theory, research and practice (pp. 288-313). San Francisco, CA: Jossey-Bass, Inc.

Pertschuk, M. (2001). Smoke in their eyes: Lessons in movement leadership from the tobacco wars. Nashville, TN: Vanderbilt University Press.

Rogers, E. M. (1983). Diffusion of innovations (3rd ed.). New York: Free Press.

Rogers, E. M. (1995). Diffusion of innovations (4th ed.). New York: Free Press.

Rogers, E. M. (2003). Diffusion of innovations (5th ed.) New York: Free Press. 
Rogers, E.M. \& Dearing, J.W. (1988). Agenda-setting research: Where has it been, where is it going? In James A. Anderson (Ed.), Communication Yearbook, (11), 555-594. Newbury Park, CA: Sage.

Schattschneider, E.E. (1960). The Semisovereign People: A Realist's View of Democracy in America. New York: Holt, Rinehart and Winston.

Sullivan, L.W. (1991). Partners in prevention: A mobilization plan for implementing Healthy People 2000. American Journal of Health Promotion, 5(4), 291-297.

\title{
Acknowledgement
}

This article was partially supported by a grant from the Paso del Norte Health Foundation through the Center for Border Health Research. Its contents are solely the responsibility of the authors and do not necessary represent the official views of the Paso del Norte Health Foundation or the Center for Border Health Research.

\author{
Author Information \\ Charles (Chuck) T. Kozel, PhD, MPH, CHES* \\ Assistant Professor \\ Department of Health Science \\ MSC 3 HLS \\ PO Box 30001 \\ New Mexico State University \\ Las Cruces, NM 88003-8001 \\ Ph.: 505-646-2864 \\ Ph.: 505-496-6641 (cell) \\ E-Mail: ckozel@nmsu.edu \\ William M. Kane, PhD, CHES, Professor \\ Community Health Education Program \\ University of New Mexico \\ Michael T. Hatcher, DrPH, MPH, CHES \\ Chief, Program Services Branch \\ Division of Health Education and Promotion \\ Agency for Toxic Substances and Disease Registry (ATSDR) \\ Atlanta, Georgia (404) 498-0323 \\ E-Mail: mth1@cdc.gov or mhatcher@cdc.gov \\ Anne P. Hubbell, PhD, Assistant Professor \\ Department of Communication Studies \\ MSC 3 W, P.O. Box 30001 \\ New Mexico State University \\ Ph.: 505-646-1603 \\ E-Mail: ahubbell@nmsu.edu \\ James W. Dearing, PhD, Professor \\ School of Interpersonal Communication \\ Ohio University \\ Athens, $\mathrm{OH}$ \\ E-Mail: dearingj@ohiou.edu \\ Sue Forster-Cox, PhD, MPH, CHES, Assistant Professor \\ Department of Health Science
}


MSC 3 HLS, PO Box 30001

New Mexico State University

Las Cruces, NM 88003-8001

E-Mail: sforster@nmsu.edu

Sharon Thompson, PhD, MPH, CHES, Assistant Professor College of Health Sciences

Health Sciences Program

1101 N. Campbell St.

University of Texas at El Paso

El Paso, TX 79902

Ph.: 915-747-7221

E-Mail: sthompson@utep.edu

Frank G. Pérez, PhD, Assistant Professor

Department of Communication

University of Texas at El Paso

El Paso, TX 79902

Ph.: 915-747-5310

E-Mail: frankgperez@yahoo.com

Melanie Goodman, MPH

New Mexico State University

Las Cruces, NM 88003-8001

* corresponding author 


\section{Appendix A}

\section{Health Promotion Agenda-Setting Terminology}

\begin{tabular}{|c|c|}
\hline \multicolumn{2}{|r|}{ Health Promotion Agenda Setting - Key Terms } \\
\hline Agenda & $\begin{array}{l}\text { Set of issues communicated in a hierarchy (rank order) of importance in time } \\
\text { (Dearing and Rogers, 1996). }\end{array}$ \\
\hline Agenda-Setting & $\begin{array}{l}\text { Narrows the set of conceivable subjects/problems/issues to the set that actually } \\
\text { becomes the focus of attention (Kingdon, 2003). }\end{array}$ \\
\hline \multirow[t]{5}{*}{ Agenda-Setting Process } & $\begin{array}{l}\text { Conceptualizes the process of how issues move from relative unimportance to the } \\
\text { forefront of policymakers' thoughts. }\end{array}$ \\
\hline & $\begin{array}{l}\text { Includes the media agenda, public agenda and policy agenda (Dearing and Rogers, } \\
\text { 1996), and the interrelationships among these three components. }\end{array}$ \\
\hline & $\begin{array}{l}\text { Partnership development and media advocacy are critical elements of effective } \\
\text { agenda setting. }\end{array}$ \\
\hline & $\begin{array}{l}\text { Agenda-setting represents a theory that offers cross-level analysis (Finnegan \& } \\
\text { Viswanath, 2002) }\end{array}$ \\
\hline & $\begin{array}{l}\text { Utilizes roles of local newspapers and community partnerships in community health } \\
\text { initiatives (Hubbell, \& Dearing, 2003) }\end{array}$ \\
\hline \multirow[t]{2}{*}{$\begin{array}{l}\text { Health Promotion } \\
\text { Agenda-Setting }\end{array}$} & $\begin{array}{l}\text { Planned process for redirecting health promotion approaches and public health } \\
\text { leadership for innovative health policy formulation. }\end{array}$ \\
\hline & $\begin{array}{l}\text { Sets, directs and implements the agenda for health promotion and disease } \\
\text { prevention, tailoring strategies and methods for each agenda-setting domain (public, } \\
\text { media and policy) (Kozel, Kane, Rogers \& Hammes, 1995). }\end{array}$ \\
\hline \multirow[t]{4}{*}{$\begin{array}{l}\text { Health Promotion } \\
\text { Agenda Building } \\
\text { Concepts }\end{array}$} & $\begin{array}{l}\text { Refocusing Upstream - rather than downstream services applied "after” the damage } \\
\text { is done, refocusing upstream addresses the manufacturers of illness and utilizes } \\
\text { political-economic interventions involving legislation } \\
\text { (McKinlay, 1975). }\end{array}$ \\
\hline & $\begin{array}{l}\text { Use of Partnerships - Collaborating with local, state, regional, national and } \\
\text { international organizations provides the strength and momentum to improve health } \\
\text { promotion and disease prevention goals (Sullivan, 1991). }\end{array}$ \\
\hline & $\begin{array}{l}\text { Media Advocacy - The strategic use of mass media redefines previously perceived } \\
\text { "individual” problems to issues requiring governmental remediation (Dearing \& } \\
\text { Rogers, 1996). }\end{array}$ \\
\hline & $\begin{array}{l}\text { Innovation and Diffusion - Communicating with acceptable channels over time } \\
\text { spreads a new idea from its creation to its ultimate adoption by reaching the critical } \\
\text { mass (Rogers, 1983; } 1995 \text { \& 2003) }\end{array}$ \\
\hline $\begin{array}{l}\text { Health Promotion } \\
\text { Agenda-Setters }\end{array}$ & $\begin{array}{l}\text { Using agenda-setting practices, set more effective health promotion agendas and } \\
\text { introduce an innovative advocacy approach to improve health policy formulation, } \\
\text { adoption and quality of life. }\end{array}$ \\
\hline $\begin{array}{l}\text { Health Promotion } \\
\text { Agenda-Setting Research }\end{array}$ & $\begin{array}{l}\text { Provides preliminary data to build upon emerging public health evidence regarding } \\
\text { deficiencies in the public health infrastructure for transforming health promotion } \\
\text { leadership. }\end{array}$ \\
\hline
\end{tabular}

